\title{
Surgical thrombectomy versus conservative treatment in cases of acute limb ischemia with COVID-19 pneumonia
}

\author{
Fahad A.M. ${ }^{1}$, Al-Khalidi H. A. ${ }^{2}$, Altimimi Y.Q.M. ${ }^{3}$ \\ ${ }^{1}$ Department of Cardiovascular Surgery, Najaf Health Directorate, Al-Sadder Teaching Medical City. Najaf; ${ }^{2}$ Faculty of Medicine, \\ Kufa university; Middle Euphrates Neurosciences Center. Najaf; ${ }^{3}$ Cardiothoracic and Vascular Surgery Department, \\ Al-Sadder Teaching Hospital. Misan, Iraq
}

See "Acute lower limb ischemia in the context of the COVID-19 pandemic" Vinokurov I. A. and "Thrombectomy vs conservative therapy in patients with COVID-19" Kazantsev A. N. in Opinion of invited editor, pp. 96-98 and pp. 99-101

COVID-19 infection is a major cause for acute respiratory distress syndrome, multi-organ dysfunction, coagulopathy, and intravascular thrombosis; therefore, it is the main causative factor for acute limb ischemia.

Aim. To compare the treatment outcome of two limb ischemic groups post COVID-19 infection in a single center and detect at least which is better for the patients in the period of COVID-19 pandemic.

Material and methods. Here, in this study, we collect 26 patients and divided them into two groups, G1 (14) patients treated conservatively and G2 (12) patients treated with surgical thrombectomy. Data were analyzed to look for the outcome of groups after 24 hours and 30 days. Results. The successful rate of conservative treatment was $85,72 \%$ in G1, while it was $75 \%$ in $\mathrm{G} 2$. There were two amputations below the knee joint in each group. Three patients died in both groups.

Conclusion. In conclusion, both conservative treatment and surgical thrombectomy have a comparable successful rate in the selected group of COVID-19 patients.

Keywords: COVID-19, limb ischemia, thrombectomy, pneumonia, coagulopathy.

\section{Relationships and Activities: none.}

Fahad A. M. * - MD, PhD, Clinical Cardiothoracic \& Vascular surgeon, Senior researcher, ORCID: 0000-0003-2810-2810, Al-Khalidi H. A. MD, PhD, Clinical Neurologist, Leading researcher, ORCID: 0000-00023357-4858, Altimimi Y. Q. M. - MD, PhD, Clinical Cardiothoracic \& Vascular surgeon, researcher, ORCID: 0000-0003-3748-681X.

*Corresponding author: ayam.mohammad@yahoo.com

Received: 17/04-2021

Revision Received: 21/04-2021

Accepted: 10/05-2021

\section{(cc) BY 4.0}

For citation: Fahad A. M., Al-Khalidi H. A., Altimimi Y. Q. M. Surgical thrombectomy versus conservative treatment in cases of acute limb ischemia with COVID-19 pneumonia. Кардиоваскулярная терапия и профилактика. 2021;20(4):2885. doi:10.15829/1728-8800-20212885

\section{Сравнительный анализ результатов применения тромбэктомии и консервативного лечения при острой ишемии конечностей у пациентов с COVID-19-ассоциированной пневмонией}

Fahad A. M. ${ }^{1}$, Al-Khalidi H. A. ${ }^{2}$, Altimimi Y. Q. M. ${ }^{3}$

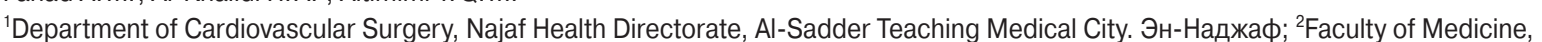
Kufa University; Middle Euphrates Neurosciences Center. Эн-Наджаф; ${ }^{3}$ Cardiothoracic and Vascular Surgery Department, Al-Sadder Teaching Hospital. Майсан, Ирак

Читайте статьи “Острая ишемия нижних конечностей в условиях пандемии COVID-19" Винокурова И. A. и "Tромбэктомия vs консервативное лечение у больных с COVID-19” Казанцева А. Н. в разделе Мнение приглашенного редактора, стр. 96-98 и стр. 99-101

На сегодняшний день, инфекция COVID-19 является одной из главных причин развития острого респираторного дистресс-синдрома, полиорганной недостаточности, коагулопатии и внутрисосудистого тромбоза. Следовательно, это основной причинный фактор формирования острой ишемии конечностей.
Цель. В ходе одноцентового исследования сравнить результаты лечения пациентов с ишемией конечностей и сопутствующей инфекцией COVID-19.

Материал и методы. В настоящее исследование было включено 26 пациентов, которые были разделены на две группы: первая

*Автор, ответственный за переписку (Corresponding author):

e-mail: ayam.mohammad@yahoo.com

[Fahad A. M. ${ }^{\star}-$ MD, PhD, Clinical Cardiothoracic \& Vascular surgeon, Senior researcher, ORCID: 0000-0003-2810-2810, Al-Khalidi H. A. - MD, PhD, Clinical Neurologist, Leading researcher, ORCID: 00000002-3357-4858, Altimimi Y. Q. M. - MD, PhD, Clinical Cardiothoracic \& Vascular surgeon, researcher, ORCID: 0000-0003-3748-681X]. 
группа (n=14) - пациенты, подвергнутые консервативному лечению; вторая группа (n=12) - пациенты, перенесшие хирургическую лечение - тромбэктомию. Результаты лечения были оценены через 24 часа и 30 дней.

Результаты. Консервативное лечение оказалось эффективным в 85,72\% случаев, тогда как тромбэктомия - в 75\%. В каждой группе было зарегистрировано две ампутации ниже коленного сустава Кроме того, в каждой группе произошли 3 летальных исхода.

Заключение. По результатам исследования, как консервативное лечение, так и тромбэктомия имеют сопоставимую эффективность при острой ишемии конечностей у пациентов с COVID-19.

Ключевые слова: COVID-19, ишемия конечностей, тромбэктомия пневмония, коагулопатия.

\section{Introduction}

Coronavirus disease 2019 (COVID-19) is a pandemic and worldwide spreading infection that represents the main cause for acute respiratory distress syndrome, multi-organ dysfunction, upper and lower respiratory tract symptoms, subdural hematoma, hypercoagulopathy, and disseminated vascular thrombosis [1-4]. A coagulopathy is documented in up to $50 \%$ of patients with severe COVID-19 infection in form of elevated D-dimer, and this may be linked to higher mortality $[5,6]$. An increased level of D-dimer may be linked to inflammation in COVID-19 and have limited predictive value for thrombosis [7]. Thrombosis in patients with COVID-19 can be caused by coagulopathy, complement system activation, inflammation, platelet hyperactivity, thrombocytopathy, and endotheliopathy [8].

Acute limb ischemia is one of the common vascular conditions in an emergency unit that may be caused by sudden thrombotic occlusion in a previously treated segment or atherosclerotic diseased arteries or caused by hypercoagulopathy in native arteries $[6,9,10]$. The clinical state of limb ischemia can be assessed using Rutherford's classification for acute limb ischemia (ALI) [11]. The treatment of limb ischemia may result in limb salvage, whereas delay can lead to limb loss and death [12]. The clinical stage of the ischemia determines the type of treatment, either immediate surgical revascularization (embolectomy) in severe ischemia or endovascular interventions (catheter-directed thrombolysis) for moderate ischemia [11].

In this single-center study, we compare the treatment outcome of two limb ischemic groups post COVID-19 infection and detect at least which is better for the patients in the period of COVID-19 pandemic.

\section{Material and methods}

Study design and setting. This is an observational prospective cohort study done in Al-Sadder Teaching Medical City for three months from July to October 2020. The study included 26 patients presented at isolation COVID-19 center with lower or upper ALI.

Participants. We subdivided the patients into two groups: G1 - patients treated conservatively and G2 - patients treated surgically. G1 included 14 patients, while G2 included
Отношения и деятельность: нет.

Поступила 17/04-2021

Получена рецензия 21/04-2021

Принята к публикации 10/05-2021

Для цитирования: Fahad A. M., Al-Khalidi H.A., Altimimi Y. Q. M. Сравнительный анализ результатов применения тромбэктомии и консервативного лечения при острой ишемии конечностей у пациентов с COVID-19-ассоциированной пневмонией. Кардиоваскулярная терапия и профилактика. 2021;20(4):2885. doi:10.15829/1728-8800-2021-2885

12 patients. The selection of patients in each group was carried out according to certain criteria.

Patients were selected into G1 if they had the followings:

1. They were unfit for surgery generally (on the ventilator, shocked patients, coma).

2. Patient with class I Rutherford limb ischemia (good sensory, good motor and audible arterial and venous flow).

3. Duration of ischemia for more than 24 hours.

4. There was a distal arterial occlusion according to doppler ultrasound including distal radial, ulnar, anterior tibial (ATA), posterior tibial (PTA), peroneal, and dorsalis pedis arteries.

Patients were selected into G2 if they had the followings:

1. They were fit for surgery generally.

2. Duration of ischemia for less than 24 hours.

3. There was a proximal arterial occlusion according to doppler ultrasound including axillary, brachial, common femoral (CFA), superficial femoral (SFA), popliteal arteries, proximal half of radial, ulnar, ATA, PTA, peroneal and dorsalis pedis arteries.

4. Patient with class II Rutherford limb ischemia (minimal both sensory and motor function, inaudible arterial and audible venous flow).

Data collection. The history was taken from each patient including information on comorbidities, age, sex, duration of COVID-19 and ischemia, prior history of ischemia. A thorough examination of the patient was done, including a general, cardiovascular, respiratory, neurological, and local ischemic limb examinations. The severity of ischemia was assessed using Rutherford classification for ALI [11]. Patient basic blood investigations, D-dimer determination, electrocardiography, chest $\mathrm{X}$-ray, and chest computed tomography were performed. Echocardiography was done to rule out ventricular thrombus or pulmonary embolism. Patients were underwent to doppler arterial and venous ultrasound to localize the place and flow of limb arteries.

Patients with class III Rutherford limb ischemia (paralytic limb, inaudible arterial and venous flow), cardiac thrombus, and a combination of deep vein thrombosis and limb ischemia were excluded from the study.

Intervention. Patients from G1 received a full dose of systemic anticoagulant heparin (loading dose $80 \mathrm{mg} / \mathrm{kg}$ / $\mathrm{hr}$, maintenance dose $18 \mathrm{mg} / \mathrm{kg} / \mathrm{hr}$ ). In G1 patients, the surgery was done through (S) shaped incision for upper limb ischemia and longitudinal inguinal one for an infra-inguinal lesion or posterior knee incision for infra-genicular lower limb ischemia under local anesthesia (lidocaine local injection $3 \mathrm{mg} / \mathrm{kg}$ without adrenalin) and sedation. All patients received an oxygen mask and prophylactic antibiotic. Arterial 
Table 1

Differences between $\mathrm{G} 1$ and $\mathrm{G} 2$ results depending on age, sex, limb involved, side of lesion, duration of ischemia, onset after COVID-19 and D-dimer levels

\begin{tabular}{|c|c|c|c|}
\hline Parameter & Group 1 (G1) & Group 2 (G2) & p-value \\
\hline Number of patients & 14 & 12 & \\
\hline Age (years) & $65 \pm 7,60$ & $58 \pm 12,99$ & 0,136 \\
\hline \multirow[t]{2}{*}{ Sex } & $10(71,42 \%)$ & $8(66,66 \%)$ & 0,793 \\
\hline & $4(28,57 \%)$ & $4(33,33 \%)$ & \\
\hline \multirow[t]{2}{*}{ Limb } & $2(14,28 \%)$ & $6(50 \%)$ & 0,049 \\
\hline & $12(85,71 \%)$ & $6(50 \%)$ & \\
\hline \multirow[t]{2}{*}{ Side } & $12(85,71 \%)$ & $6(50 \%)$ & 0,049 \\
\hline & $2(14,28 \%)$ & $6(50 \%)$ & \\
\hline Ischemia duration (hr) & $48 \pm 9,44$ & $22 \pm 5,05$ & 0,0002 \\
\hline Onset after COVID-19 (days) & $15 \pm 6,44$ & $17 \pm 3,52$ & 0,462 \\
\hline D-dimer (ng/mL) & $1302 \pm 753,94$ & $1810 \pm 651,20$ & 0,249 \\
\hline
\end{tabular}

embolectomy was done with Fogarty catheter (size of catheter varied from $3 \mathrm{f}$ to $6 \mathrm{f}$ ). After embolectomy, irrigation of ischemic limb with heparinized saline (5000 units heparin with 100 $\mathrm{ml}$ of normal saline) was performed, then the patient kept on systemic heparin.

Follow-up. Patients from both groups were followed for 24 hours and after one month, both clinically and by Doppler study to look for complications. Surgery for G2 or treatment for G1 were considered successful if there was no early reocclusion or was a clinical resolution of ischemia ( $<30$ days) or absence of amputation or death within 48 hours.

Oral and written informed consent from all patients were taken.

Statistical analysis. The data were analyzed using Microsoft Excel version 2009 and a social statistical calculator. The data were presented as number, mean, standard deviation, and percentage. Differences were considered significant at $p<0,05$.

\section{Results}

This study included 26 patients divided into G1 $(n=14$; conservative treatment) and $G 2(n=12$; surgical embolectomy). No patients with previous vascular surgery were in both groups. The mean age in G1 was $65 \pm 7,60$ (range from 49 to 70 years), in G2 $-58 \pm 12,99$ (range from 42 to 70 years). There were more males in both groups: in G1, 10 patients $(71,42 \%)$ were males and 4 patients were females $(28,57 \%)$; in G2, $8(66,66 \%)$ and 4 patients $(33,33 \%)$, respectively (Table 1$)$.

In $\mathrm{G} 1$, we treated 12 lower and 2 upper limbs, while in $\mathrm{G} 2-6$ upper and 6 lower limbs. Regarding the side of involvement, in G1 - 12 right and 2 left sides, and in G2 -6 right and 6 left sides. Regarding the involvement vessel, in G1 - 10 cases both distal ATA and PTA were involved in the leg, two cases in foot arteries, and two cases both distal ulnar and radial arteries were involved. In G2, there were four cases of CFA involvement, two - SFA and popliteal arteries, four - brachial artery, and two - axillary artery (Table 1).

Duration of ischemia was $48 \pm 9,44$ and $22 \pm 5,05 \mathrm{hr}$ in $\mathrm{G} 1$ and $\mathrm{G} 2$, respectively. The time of ischemia from
Results of both study groups

\begin{tabular}{lll}
\hline Parameter & Group 1 (G1) & Group 2 (G2) \\
\hline Re-occlusion & 0 & $1(8,33 \%)$ \\
\hline Amputation & $2(14,28 \%)$ & $2(16,66 \%)$ \\
\hline Death & $2(14,28 \%)$ & $1(8,33 \%)$ \\
\hline Fasciotomy & - & 0 \\
\hline G1 need surgery & 0 & - \\
\hline Successful treatment & $85,72 \%$ & $75 \%$ \\
\hline
\end{tabular}

the COVID-19 onset was $15 \pm 6,44$ and $17 \pm 3,52$ days, respectively. D-dimer level in G1 was $1302 \pm 753,94$ $\mathrm{ng} / \mathrm{mL}$, while in $\mathrm{G} 2-1810 \pm 651,20 \mathrm{ng} / \mathrm{mL}$ as shown in Table 1. There were 10 patients with comorbidities: 6 patients were smokers, 4 patients have multiple multimorbidity (diabetes, smoking, hypertension).

Regarding the follow-up, no patient in G2 needs fasciotomy after surgery, no patient in G1 needs surgery. One patient of G2 $(8,33 \%)$ had re-occlusion of brachial artery after 36 hours and needed for a new surgery. In two patients of G1 $(14,28 \%)$, an amputation below the knee joint was performed: in one case, after three days (foot vessels involvement, 62 years of age); in another one, after five days (both ATA and PTA involvement, 70 years of age). Also, two patients in G2 underwent an amputation below the knee joint $(16,66 \%)$, both within two days after surgery: in one case, CFA was involved (66 years of age); in another one, SFA and popliteal artery were lesioned (67 years of age). Three patients died due to COVID-19 pneumonia: two patients from G1 (14,28\%; age, 62 and 68 years) less than 24 hours; one patient from $\mathrm{G} 2(8,33 \%$; age, 67 years) after 5 days. The successful rate in $\mathrm{G} 1$ was $85,72 \%(\mathrm{n}=12)$, while in $\mathrm{G} 2,75 \%(\mathrm{n}=9)$, (p-value $<0,489)$ as shown in Table 2.

\section{Discussion}

COVID-19 is a global infection that spreads widely in many countries, including Iraq and it affects especially the respiratory system via its passing to cells through angiotensin-converting enzyme II receptors, which are present in type II pneumocyte of the lung [13, 14]. COVID-19 infection is associated with coagulation abnormality in form of vascular thrombosis [15]. In the study by Abou-Ismail, et al., the elevation of D-dimer was associated with coagulopathy and this may have a worse outcome regarding morbidity and mortality [15]. This agrees with the study by Lodigiani, et al., which showed differences between D-dimer level in survivors and deceased patients as follows: 353-529 and 869$1494 \mathrm{ng} / \mathrm{mL}$, respectively [16]. In our study, D-dimer level in all our patients was elevated in both groups $(1302 \pm 753,94 \mathrm{ng} / \mathrm{ml}$ for $\mathrm{G} 1$ and $1810 \pm 651,20 \mathrm{ng} / \mathrm{ml}$ for G2). So, this is associated with thrombosis and ALI, which explains why are incidence of ALI increased during the COVID-19 infection period as shown in Bellosta R, et al. study in Italy [6]. 
In this study, not all patients with ALI during the study period were included. The study excludes patients with deep vein thrombosis or advanced ischemia characterized by paralytic limb, inaudible arterial and venous Doppler flow because these are indications for amputation, but not for conservative or surgical revascularization [17]. In addition, the study excludes those with cardiac thrombus diagnosed with an echocardiography to rule out the cardiac cause of ischemia.

The diagnosis of ALI in these COVID-19 patients depends on clinical findings and confirm that with doppler ultrasound in the same hospital, we can't refer them for computed tomography angiography because, in addition to it is limited use in ALI [11], there is difficulty in transferring the critical patients to a remote area.

In our study, we divided the patients into two groups: G1 - conservative therapy; G2 - surgical embolectomy. G1 include patients with class I Rutherford limb ischemia (good sensory, good motor, and audible arterial and venous flow) [17], those unfit for surgery (on a ventilator, shocked patients, coma), or those with the ischemia time more than 24 hours, or those with distal ischemia. G2 include patients with class II Rutherford ischemia with minimal both sensory and motor function, inaudible arterial and audible venous flow, if they were fit for surgery and had ischemia time less than 24 hours [17].

There was a proximal arterial occlusion according to doppler ultrasound including axillary, brachial, CFA, SFA, popliteal, proximal half of radial, ulnar, ATA, PTA, peroneal and dorsalis pedis arteries [17].

We never select catheter-directed thrombolysis because it is not available during the infection. However, study by Enezate, et al. with 1773 patients showed that endovascular and surgical options for ALI have identical rates of mortality, amputation, and recurrent ischemia [17]. Also, we can't use post-operative conventional angiography because it is unavailable in our operative theatres. We use post-thrombectomy heparin infusion to prevent distal microcirculation thrombosis, both due to the hypercoagulability state of the disease and difficulties to retrieve during thrombectomy.

In Enezate TH, et al. study, the mean age was 67 years and $65 \%$ of patients were males [18], while in G1 of our study, the mean age was $65 \pm 7,60$ years (10 males and 4 females) and in $\mathrm{G} 2,58 \pm 2,99$ years (8 males and 4 females). In Bellosta R, et al. study, 18 patients were men and two were women and the mean age was $75 \pm 9$ years (range, 62-95 years) [6].

\section{References}

1. Al-Khalidi H, Hassoun H, Aljid Z, Allebban Z. COVID-19 Related Spinal Subdural Hematoma Presented with Acute Compressive Myelopathy. Authorea. Preprint;12, 2020. doi:10.22541/ au.160516630.00713824/v1.

2. Anwar S, Acharya S, Shabih S, Khabut A. Acute Limb Ischemia in COVID-19 Disease: A Mysterious Coagulopathy. Cureus. 2020;12(7):e9167. doi:10.7759/cureus.9167.
The successful rate of treatment for both groups was 85,72 and $75 \%$ for $\mathrm{G} 1$ and $\mathrm{G} 2$, respectively. In the study by Bellosta R, et al., successful rate was $70,6 \%$ (only in 12 out of 17 patients) [6]. There was one patient in G2 with re-occlusion of brachial artery after 36 hours $(8,33 \%)$, who needed a resurgery due to re-thrombosis, while in the study Bellosta R, et al., there were two patients $(13 \%)$ with re-thrombosis who needed surgery after 1 and 2 days, respectively [6].

In Perini P, et al. study, 53-year-old patient was rethrombosed after 2 hours of thrombectomy and he died after two days due to multiple comorbidities [19]. Two patients in G2 had an amputation below the knee joint $(16,66 \%)$ (one with CFA involvement, 66 years of age; another one, SFA and popliteal artery involvements, 67 years), both within two days after operation, while in the study by Bellosta R, et al., one patient aged 81 years underwent an amputation after the unsuccessful procedure [6]. In addition, in the study by Gubitosa JC, et al., the patient received fondaparinux and underwent thrombectomy due to limb ischemia, followed by an amputation above the knee in next day [20]. There were two deaths in G1 $(14,28 \%$; one patient, 62 years of age; another one, 68 years of age) less than 24 hours, while in Bellosta, et al. study, there were eight out of 20 deaths, four of them - within 2 days [6].

In Aleksandrovskaya Hospital (St. Petersburg, Russia), the study by Linets YuP, et al. was conducted, where the structure of surgical complications in COVID-19 patients from the point of vascular surgeon views was analyzed [21].

Safiullina SI and Litvinov RI concluded that the comprehensive and evidence-based guidelines development on the management of COVID-19 are needed; it is also necessary to conduct comprehensive systematic studies and comparative clinical trials on prophylaxis and treatment of hemostatic disorders in COVID-19 patients [22].

\section{Conclusion}

The choice of specific treatment in patients with ALI during COVID-19 pneumonia may differ according to specific criteria of ischemia with the comparable successful rate depending on the classification of ischemia, site of thrombosis, duration of ischemia, and associated disease.

Relationships and Activities: none.

3. Fahad AM, Mohammad AA, Al-Khalidi HA, et al. Case Report: COVID-19 in a female patient who presented with acute lower limb ischemia [version 1; peer review: awaiting peer review] F1000 Research. 2020;9:778. doi:10.12688/f1000research.25319.1.

4. Singh B, Kaur P, Ajdir N, et al. Covid-19 Presenting as Acute Limb Ischemia. Cureus. 2020;12(7):e9344. doi:10.7759/ cureus.9344. 
5. Miesbach W, Makris M. COVID-19. Coagulopathy, Risk of Thrombosis, and the Rationale for Anticoagulation. Clin Appl Thromb Hemost. 2020;26:1076029620938149. doi:10.1177/1076029620938149.

6. Bellosta R, Luzzani L, Natalini G, et al. Acute limb ischemia in patients with COVID-19 pneumonia. J Vasc Surg. 2020;72(6):1864-72. doi:10.1016/j.jvs.2020.04.483.

7. Yu B, Li X, Chen J, et al. Evaluation of variation in D-dimer levels among COVID-19 and bacterial pneumonia: a retrospective analysis. J Thromb Thrombolysis. 2020;50(3):548-57. doi:10.1007/s11239-020-02171-y.

8. Gu SX, Tyagi T, Jain K, et al. Thrombocytopathy and endotheliopathy: crucial contributors to COVID-19 thromboinflammation [published online ahead of print, 2020 Nov 19]. Nat Rev Cardiol. 2020;1-16. doi:10.1038/s41569-020-00469-1.

9. O'Connell JB, Quiñones-Baldrich WJ. Proper evaluation and management of acute embolic versus thrombotic limb ischemia. Semin Vasc Surg. 2009;22:10-6. doi:10.1053/j. semvascsurg.2008.12.004.

10. Deitcher SR, Carman TL, Sheikh MA, Gomes M. Hypercoagulable syndromes: evaluation and management strategies for acute limb ischemia. Semin Vasc Surg. 2001;14:74-85. doi:10.1053/ svas.2001.23156.

11. Olinic DM, Stanek A, Tătaru DA, et al. Acute Limb Ischemia: An Update on Diagnosis and Management. J Clin Med. 2019;8(8):1215. doi:10.3390/jcm8081215.

12. Walker TG. Acute Limb Ischemia. Techniques in Vascular and Interventional Radiology, 2009;12(2):117-29. doi:10.1053/j. tvir.2009.08.005.

13. Fahad AM, Mohammad AA, Al-Khalidi HA, Alshewered AS. Spontaneous pneumothorax as a complication in COVID-19 male patient: A case report. Clin Case Rep. 2020;8(12):3116-9. doi:10.1002/ccr3.3378.

14. Fahad AM, Al-Khalidi HA, Abdulhameed YA, et al. Pleural effusion in a patient with COVID-19 pneumonia and lung cancer: a case report. Respiratory medicine case report. 2020;31:101302. doi:10.1016/j.rmcr.2020.101302.
15. Abou-Ismail MY, Diamond A, Kapoor S, et al. The hypercoagulable state in COVID-19: Incidence, pathophysiology, and management. Thromb Res. 2020;194:101-15. doi:10.1016/j. thromres.2020.06.029.

16. Lodigiani C, lapichino G, Carenzo L, et al.; Humanitas COVID-19 Task Force. Venous and arterial thromboembolic complications in COVID-19 patients admitted to an academic hospital in Milan, Italy. Thromb Res. 2020;191:9-14. doi:10.1016/j. thromres.2020.04.024.

17. Acar RD, Sahin M, Kirma C. One of the most urgent vascular circumstances: Acute limb ischemia. SAGE Open Med. 2013;11;1:2050312113516110. doi:10.1177/2050312113516110.

18. Enezate TH, Omran J, Mahmud E, et al. Endovascular versus surgical treatment for acute limb ischemia: A systematic review and meta-analysis of clinical trials. Cardiovasc Diagn Ther. 2017;7:264-71. doi:10.21037/cdt.2017.03.03.

19. Perini $P$, Nabulsi $B$, Massoni $C B$, et al. Acute limb ischemia in two young, non-atherosclerotic patients with COVID-19. The Lancet. 2020;395(10236):1546. doi:10.1016\%2FS0140-6736(20)31051-5.

20. Gubitosa JC, Xu P, Ahmed A, Pergament K. COVID-19-Associated Acute Limb Ischemia in a Patient on Therapeutic Anticoagulation. Cureus. 2020;12(9):e10655. doi:10.7759/cureus.10655.

21. Linets YuP, Artyukhov SV, Kazantsev AN, et al. Thrombosis in the structure of surgical complications of COVID-19. Emergency. 2020;21(4):24-9. (In Russ.) Линец Ю. П., Артюхов С. В., Казанцев А. Н. и др. Тромбозы в структуре хирургических осложнений COVID-19. Скорая медицинская помощь. 2020;21(4):24-9. doi:10.24884/2072-6716-2020-21-4-24-29.

22. Safiullina SI, Litvinov RI. Recommendations for the prevention and correction of thrombotic complications in COVID-19. Kazan Medical Journal. 2020;101(4):485-8. (In Russ.) Сафиуллина С.И., Литвинов Р.И. Рекомендации по профилактике и коррекции тромботических осложнений при COVID-19. Казанский медицинский журнал. 2020;101(4):485-8. doi:10.17816/KMJ2020-485. 